This document classified by

D. E. Braden Do Bradew

Manager - Process Design and

Development

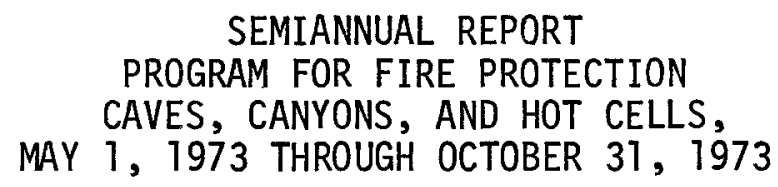

H. A. Lee

Process Design and Development

Development Engineering

Research and Engineering Division

December 14, 1973

Operated for the Atomic Energy Commission by

At1antic Richfield Hanford Company under Contract AT(45-1)-2130 


\section{DISCLAIMER}

This report was prepared as an account of work sponsored by an agency of the United States Government. Neither the United States Government nor any agency Thereof, nor any of their employees, makes any warranty, express or implied, or assumes any legal liability or responsibility for the accuracy, completeness, or usefulness of any information, apparatus, product, or process disclosed, or represents that its use would not infringe privately owned rights. Reference herein to any specific commercial product, process, or service by trade name, trademark, manufacturer, or otherwise does not necessarily constitute or imply its endorsement, recommendation, or favoring by the United States Government or any agency thereof. The views and opinions of authors expressed herein do not necessarily state or reflect those of the United States Government or any agency thereof. 


\section{DISCLAIMER}

Portions of this document may be illegible in electronic image products. Images are produced from the best available original document. 
TABLE OF CONTENTS

$\underline{\text { Page }}$

PROGRAM SCOPE AND OBJECTIVES

FIRE EXTINGUISHMENT 3

FIRE DETECTION

PROTECTION OF FILTERS DURING HOT CELL FIRES 6

THE EFFECT OF VENTILATION CONTROL ON FIRE SUPPRESSION

THE EFFECT OF SOLVENT TEMPERATURE ON THE IGNITION AND BURNING PROCESS 9

RELEASE OF AIRBORNE CONTAMINATION FROM BURNING $\begin{array}{ll}\text { RADIOACTIVE SOLVENTS } & 10\end{array}$

$\begin{array}{ll}\text { REFERENCES } & 11\end{array}$

$\begin{array}{lr}\text { TABLES } & 13-15\end{array}$ 


\author{
SEMIANNUAL REPORT \\ PROGRAM FOR FIRE PROTECTION, \\ CAVES, CANYONS, AND HOT CELLS, \\ MAY 1, 1973 THROUGH OCTOBER 31, 1973
}

PROGRAM SCOPE AND OBJECTIVES

The purpose of this program is to establish the theoretical and practical basis for providing suitable fire protection systems for nuclear caves, canyons, and hot cells. Its objective is to develop data and information for the design of fire detection and extinguishing equipment and methods for protection of these critical nuclear facilities from fire or the release of radioactive material as the result of fire. The results are to be used as the basis for a guide to be published at the conclusion of the program.

The major areas of investigation are as follows:

Fire Extinguishment

Fire Detection

Protection of Filters During Fires

Effect of Ventilation Control on Fire Suppression

Effect of Solvent Temperature on the Ignition and Burning Process

Effect of Airborne Contamination from Burning Radioactive Solvents

\title{
FIRE EXTINGUISHMENT
}

Scope and Objectives

The work on this program area is to add to the information available from the National Fire Protection Association, The Underwriters Laboratories, The Factory Mutual System, The Factory Insurance Association, and similar organizations that is applicable to fire protection in caves, canyons, and hot cells. Fires in these facilities differ from ordinary fires primarily in that they must be confined to an enclosed space. This space is often unavailable for direct manual work, whether it be for fire fighting, maintenance, or cleanup. This investigation is directed toward finding fire fighting materials and methods that can be automatically and remotely applied, are effective, and cause no serious problems of cleanup or process complication. 
Prior Work

Prior reports on this program (see references) have listed available literature on this subject and have described results of fire extinguishing experments using water and foam in a simulated hot cell.

\section{Progress During the Reporting Period}

Halon 1301 was used in test of fires involving the Purex organic solvent. The-first tests were directed at establishing the adequacy of a $2 . \overline{8}$ percent concentration of Halon applied automatically and maintained for one minute. Several tests were made (see Table I); most did not extingush the fire. It appeared in each case that the fire was extinguished but it reappeared when the Halon concentration was sufficiently reduced by the ventilation system. Several conclusions were drawn from these initial tests:

1. A 2.8 percent mixture of Halon 1301 with air maintained for one minute is too marginal to be recommended for use on hot cell fires using the Purex solvent.

2. The temperature of the solvent at time of ignition has a significant effect on the ability of Halon to extinguish the fire. That is, the higher the temperature, the more difficult the fire is to extinguish.

3. Water spray used when Halon is present is very effective on the solvent fires when the fire is redeveloping. After the Halon has been dispersed by the ventilation system, water would reduce the magnitude of the fire but required direct application to all burning areas for extinguishment.

4. The interior of the cell and all exposed metal parts showed evidence of corrosion after several tests with Hal on 1301 and water. The underlayer of water below the organic tested $0.00258 \mathrm{M}$ hydrofluoric acid. The exhaust air showed 22 parts per million of hydrogen fluoride.

5. The temperature of the solvent has a definite effect on the time of development of a fire. At $70^{\circ} \mathrm{F}$, fire in the $160^{\circ}$ flash point solvent may take a half hour to develop, depending on other factors. When the fuel is near its flash point, the fire develops rapidly and above this point care must be taken to avoid an explosion.

6. In situations where an organic solvent is operated at elevated temperatures and ventilation must be kept operating to control contamination spread, Halon system should be designed with care to assure concentration and residence time per NFPA-12A, as further defined in reference 1 . 
Evaluation of the Program Area

The information obtained on extinguishing methods has been used as the basis for the design of fire extinguishing systems for hot cells in two chemical processing plants at Hanford. This information is also applicable to similar hot cells elsewhere. However, it is often desirable to perform additional tests approximating the conditions unique to a particular hot cell prior to design of its extinguishing system.

\section{Future Work}

Additional testing of Halon extinguishing will be done using Hexone and Class A materials. Higher concentrations of Halon and longer soaking times will be tried for extinguishing fires in the Purex organic solvent. More data will be sought on the corrosion problem presented by Halon degradation products. Further tests will be carried out on the extinguishing characteristics of the Halon and water combination.

Aqueous film forming foam extinguishing tests will be extended to Hexone and Class A materials.

\section{FIRE DETECTION}

Scope and Objectives

The objective of this program area is to supplement available knowledge of fire detectors and their application to caves, canyons, and hot cells in order to achieve a maximum of reliability and sensitivity of fire detection.

\section{Prior Work}

The present state-of-the-art has been summarized by $A . J . H i 11\left({ }^{2}\right)$ and in previous reports of this program. $\left({ }^{3}-9\right)$ They show that standard detectors are the basis for detection in caves, canyons, and hot cells. Location, type, and method of use are the important variables.

\section{Progress During the Reporting Period}

One new fire detector that was developed for use with jet engines was evaluated for use in hot cells. It consists of a long tube $(10$ feet to 40 feet) that contains a gas and a gas evolving solid. It can be activated 
either by a general overtemperature of the cell or by a localized hot spot. In tests in the simulated hot cell it proved to be less sensitive than a well positioned rate compensated thermat detector and presented installation problems that made it a poor choice for use in hot cells.

Tests aimed primarily at other facets of the program also included tests of selected fire detectors (see Table II). Results continue to strengthen the conclusion that the stainless steel sheathed rate compensated thermal fire detector should be the standard to compare to when selecting a fire detector for a hot cell. Others with more sensitivity and speed of detection, such as infrared detectors or ionization detectors, are excellent as early warning devices for use where failure to operate or a false alarm will not have disastrous consequences.

\section{Evaluation of the Program Area}

The remotely testable, rate compensated thermal detector described in the last report $\left({ }^{9}\right)$ has been installed in the ventilation exhaust tunnel of one of the nuclear separations plants at Hanford. Prior to installation, it was tested at various flow rates for testability in place. The results are shown on Table III. Since installation, it has been tested in place successfully.

Future Work

Although there is not much really new in the area of fire detection, occasionally promising new models appear; these will be evaluated for adaptability to hot cell use.

\section{PROTECTION OF FILTERS DURING HOT CELL FIRES}

Scope and Objectives

During a fire in a hot cell, the exhaust ventilation system must be kept operating to prevent fire caused pressure from discharging contaminated smoke to the environs. To do this, the filters must be protected from heat, smoke, and burning material. The main effort in developing methods and equipment for this task is being carried out by Lawrence Livermore Laboratory. Work done by Atlantic Richfield Hanford Company wil1 supplement this work in some areas and will serve to corroborate in others.

\section{Prior Work}

Tests at Hanford, Rocky Flats, and Livermore have shown that the heat from a hot cel1 fire can be effectively removed by water sprays. $(11,12,13)$ Burning material can be stopped by carefully selected and installed screens. (14) A solution to the smoke problem continues to elude us. 
Progress During the Reporting Period

A method of cooling gases from a hot cell fire to a point where they can be safely accepted into a high efficiency filter without damage has been tested and is in use at Hanford. This solution involves the cooling effect of long metal ducts from the hot cell to the filter. The gas flow is limited by a preset manual damper and the ducts are protected from external heating. Tests showed that the gases from the maximum credible fire in the hot cell can be cooled by passing through a fire screen and a relatively short run of stainless steel pipe exposed to ambient air. Calculations for determining the size and length of pipe to achieve the required cooling are described by $D$. L. Lessor of Battelle Northwest. (15)

Data from actual fire tests conducted in experiments related to this program agree fairly well with results from the calculations. Using the methods of calculation outlined here, it is possible to determine whether the heat from the maximum fire in a particular hot cell will damage its exhaust filter.

\section{Evaluation of the Program Area}

A solution to the smoke problem is urgently needed in order to have the capability of designing exhaust systems for hot cells that can remain functional during a maximum fire. This is a highly complex subject because of the infinite variety of fires and related conditions that can be involved. Any information that can be obtained on this subject could well contribute to a solution. Information obtained thus far provides means of dealing with heat and burning material that could damage filters.

\section{Future Work}

Although a great deal remains to be done on the smoke problem, this program will confine its activities to smoke characterization work related to the carryover of radioactivity from burning radioactive solvents.

\section{THE EFFECT OF VENTILATION CONTROL ON FIRE SUPPRESSION}

Scope and Objectives

It is well known that ventilation has a significant effect on the intensity and efficiency of a fire. Control of ventilation can be a major factor in the suppression of fires in caves, canyons, and hot cells. Previous testing of fires in glove boxes and hot cells has suggested that there is an advantage in 
fire control when using downdraft ventilation rather than updraft ventilation. Also, it has been proposed that cutting off the ventilation at the inlet to a hot cell will help to extinguish a fire and reduce the load of combustion products on the exhaust filters. This program area is intended to confirm or refute these theories and to establish parameters for the design of hot cells and their ventilation accessories.

Prior Work

Tests have been conducted with both updraft and downdraft ventilation. The severity of the fire was greater with the updraft but the difficulty of extinguishing was not appreciably increased. $\left({ }^{9}\right)$

Progress During the Reporting Period

Additional testing both with updraft ventilation and downdraft ventilation has verified the distinct difference between the fires to be expected in the one type system as compared to the other.

In every case the fire was more severe when updraft was used in the simulated hot cel1. Temperatures rose faster early in the fire; pressures in the cell, causing emission of smoke from the cell, were more definite. Oxygen content of the exhaust gas went much lower; smoke concentration was lower. It is apparent that downdraft ventilation should be used in hot cells in the absence of some other overriding consideration.

\section{Evaluation of the Program Area}

Results of the testing in the simulated hot cell indicate there is a very good possibility of reducing the magnitude of hot cell fires and also reducing the difficulty of extinguishing by controlling the ventilation. The principal problem is the potential danger of explosion in special cases where the fuel is especially volatile. This program area should lead to criteria for this facet of the design of caves, canyons, and hot cells.

\section{Future Work}

Additional tests are planned during which data will be taken on the effect of ventilation on cell fires. The intent is to compare the fires on the basis of cell ventilation and evaluate ventilation control as a fire control tool. 
THE EFFECT OF SOLVENT TEMPERATURE ON THE IGNITION AND BURNING PROCESS

Scope and Objectives

Organic solvents are sometimes used at elevated temperatures in caves, canyons, and hot cells. The additional danger from easier ignition and greater rapidity of fire development is suspected but not quantitatively known. This study is intended to define these dangers and to develop methods of coping with them.

\section{Prior Work}

Certain information on the combustion characteristics of organic solvents is available from texts and from the manufacturers of the solvents. Additional information needed has been defined, and a program to obtain this information has been started.

\section{Progress During the Reporting Period}

Data taken during tests of detectors and extinguishing show that the solvent temperature has a marked effect on the development time of fire in Purex organic solvent.

If the operating temperature of the process is near or above the flash point of the solvent, early detection and extinguishment of the fire becomes more important to prevent damage to equipment in the cell or to the exhaust system.

\section{Evaluation of the Program Area}

This program area promises to produce information that will be valuable in the evaluation of flammable liquid hazards.

\section{Future Work}

A report on the ignition temperatures of various solvents and the rate of combustion under various circumstances will be issued when the remainder of this work is completed. 
RELEASE OF AIRBORNE CONTAMINATION FROM BURNING RADIOACTIVE SOLVENTS

Scope and Objectives

The objective is to measure the nominal fractional airborne release of radioactive materials from a "standing pool" fire involving 30 percent tributyl phosphate (TBP) in a kerosene-type diluent.

\section{Prior Work}

Data on the burning characteristics of solvents used in various nuclear fue 1 reprocessing schemes was reviewed. Variations of the "Purex Process" are predominantly used for commercial applications and, thus, 30 percent TBP in a kerosene-type diluent was chosen as the test material. Low fractional releases (one percent or less) were measured for four materials representing the nonvolatile and semivolatile materials--uranium, cesium, cerium, and zirconium--during the burning of a "standing pool" of contaminated solvent in laboratory scale experiments. Measurements were made using two regimes--self-sustaining burning to the point of spontaneous extinguishment and self-sustaining burning with heat added by propane torch to dryness. Under the same conditions, 65 and 83 percent of the iodine was made airborne, respectively. (10)

The feasibility of large scale experiments was demonstrated using the simulated hot cell. Stable isotopes of cesium, zirconium, and strontium were used as simulates since radioactive tracers cannot be used in the simulated hot cell. Preliminary data on size spectra of soot particles was obtained up and downstream of the scrubber.

\section{Progress During the Reporting Period}

Resolution of the problem areas revealed in the demonstration runs performed in the simulated hot cell is in progress. A new collection media (membrane filters) was chosen based upon the low content of the elements considered for use--cesium, cerium, strontium. Measurements by X-ray fluorescence appear to have the requisite sensitivity (10-7 grams per 10 milliliters aliquot) and can be used directly on some samples.

A new sampling train was devised and tested to protect the membrane filters at elevated temperatures. A water bubbler precedes the threeinch diameter filter to cool the hot gas and provides some particle removal capability. The distribution of activity in the sampling train and sensitivity of measurements are currently under study. 


\section{Evaluation of the Program Area}

The information sought by this program area is needed by the industry to evaluate the hazards of releasing radioactive contamination from a fire in solvents containing radioactive material. This will influence the evaluation and design of safety measures required to cope with such fires.

\section{Future Work}

Evaluation of the sensitivity of the measurement using the proposed sampling train will be completed. Large scale experiments in the simulated hot cel1 will be performed to determine the fractional airborne release of strontium during the burning of "Purex" solvent using both up- and downflow through the hot cell.

\section{REFERENCES}

(1) Paul M. Poesch1, "Large-Scale Halon 1301 Fire Test Program," pp. 35-38, Fire Journal, November 1973.

(2) DP-1242 (unclassified), Apri1 1971, A. J. Hi11, "Fire Protection in Hot Cells and Canyons," Savannah River Laboratory, Aiken, South Carolina.

(3) ARH-1990 (unclassified), February 24, 1971, H. A. Lee, "Fire Protection, Nuclear Facilities Program for FY 1971."

(4) ARH-1992 (unclassified), February 24, 1971, H. A. Lee, "Semiannual Report, Program for Fire Protection - Nuclear Facilities, May 1, 1970 through October 30, 1970."

(5) ARH-1918 (unclassified), June 1971, H. A. Lee, "A Literature Search and Analysis of Fire Protection in Nuclear Hot Cells and Filtered Exhaust Systems"

(6) ARH-2265 REV (unclassified), November 16, 1971, H. A. Lee, "Semiannual Report, Program for Fire Protection - Nuclear Facilities May 1, 1971 through October 31, 1971."

(7) ARH-2523 (unclassified), May 17, 1972, H. A. Lee, "Semiannual Report, Program for Fire Protection - Nuclear Facilities, November 1, 1971 through Apri1 30, 1972." 
(8) ARH-2667 (unclassified), December 1972, H. A. Lee, "Semiannual Report, Program for Fire Protection in Caves, Canyons, and Hot Cells, May 1, 1972 through October 31, 1972."

$\left({ }^{9}\right)$ ARH-2868 (unclassified), June 1973, H. A. Lee, "Semiannual Report, Program for Fire Protection, Caves, Canyons, and Hot Cells, November 1, 1972 through Apri1 30, 1973."

(10) BNWL-B-275 (unclassified), June 1973, J. Mishima and L. C. Schwendiman, "Interim Report: The Fractional Airborne Release of Dissolved Radioactive Materials During the Combustion of 30 Percent Normal Tributly Phosphate in a Kerosene-Type Diluent."

(11) ARH-2860 (unclassified), July 1973, P. E. Wegner, "Computation of Water Spray Required to Cool Gases from a Hot Cell Fire Prior to High Efficiency Filtration."

(12) RFP-1520 (official use on1y), November 1970, M. A. Thompson and G. A. Riordan, "Studies in the Safety of Plutonium Handling Facilities," The Dow Chemical Co., Golden, Colorado.

(13) UCRL-73800, JuTy 1972, J. R. Gaski11, J. L. Murrow, "Fire Protection of HEPA Filters Using Water Sprays," Lawrence Livermore Laboratory, Livermore, California.

(14) ARH-SA-157 (unclassified), March 1973, H. A. Lee, "Proposed Fire Protection Method for 234-5Z Building Plutonium Exhaust Systems."

(15) BNWL-B-319, November 1973, D. L. Lessor, "Duct Gas Cooling Mode1," Battelle-Northwest, Richland, Washington. 
TABLE I

HALON FIRE TESTS

\begin{tabular}{|c|c|c|c|c|c|c|c|c|c|c|}
\hline $\begin{array}{l}\text { Test } \\
\text { No. }\end{array}$ & $\begin{array}{l}\text { Air } \\
\text { Flow } \\
\text { cfm } \\
\end{array}$ & $\begin{array}{l}\text { Halon } \\
\text { Content }\end{array}$ & $\begin{array}{l}\text { Time } \\
\text { Maintained } \\
\end{array}$ & $\begin{array}{l}\text { Amount } \\
\text { Fuel } \\
\end{array}$ & $\begin{array}{l}\text { Fue 1 } \\
\text { Temp. }\end{array}$ & $\begin{array}{l}\text { Time to } \\
\text { System } \\
\text { Discharge } \\
\end{array}$ & $\begin{array}{c}\text { Max. Cell } \\
\text { Temp. } \\
\end{array}$ & $\begin{array}{l}\text { Time to } \\
\text { Extinguish }\end{array}$ & $\begin{array}{l}\text { Time Till } \\
\text { Fire Visible } \\
\text { After Halon } \\
\end{array}$ & $\begin{array}{l}\text { Time of } \\
\text { Water Use to } \\
\text { Extinguish }\end{array}$ \\
\hline 1 & 1000 & $2.8 \%$ & 1 min. & 10 gal. & $67^{\circ} \mathrm{F}$ & $37 \mathrm{~min}$. & $150^{\circ} \mathrm{C}$ & $\approx 10 \mathrm{sec}$ & -- & -- \\
\hline 2 & 1000 & $1.8 \%$ & 1 min. & 15 gal. & $180^{\circ} \mathrm{F}$ & $1 \mathrm{~min}$. & $450^{\circ} \mathrm{C}$ & Did Not & 0 & 1 min. \\
\hline 3 & 1000 & $2.8 \%$ & $10 \mathrm{sec}$ & $\approx 25 \mathrm{gal}$. & $150^{\circ} \mathrm{F}$ & $3 \mathrm{~min}$. & $260^{\circ} \mathrm{C}$ & Did Not & $2-1 / 2 \mathrm{~min}$. & $2 \min$. \\
\hline 4. & 1000 & $2.8 \%$ & $60 \mathrm{sec}$. & $\approx 25 \mathrm{gat}$ & $175^{\circ} \mathrm{F}$ & $3 \mathrm{~min}$. & $250^{\circ} \mathrm{C}$ & Did Not & $2 \min$. & $\begin{array}{l}3 \text { min. + } \\
2 \text { min. + } \\
10 \text { min. }\end{array}$ \\
\hline 5. & 1000 & $2.8 \%$ & $60 \mathrm{sec}$. & $10 \mathrm{ga} 7$. & $140^{\circ} \mathrm{F}$ & $30 \mathrm{sec}$. & $225^{\circ} \mathrm{C}$ & Did Not & $6 \mathrm{~min}$. & $40 \mathrm{sec}$. \\
\hline
\end{tabular}


TABLE II

FIRE DETECTOR RESPONSE

\section{FIRE DETECTOR AND LOCATION}

\begin{tabular}{lrrrrrr} 
Test No. & $1-\mathrm{l}$ & $\underline{2-C}$ & $\underline{3-C}$ & $\underline{4-M}$ & $\underline{2-D}$ & $\underline{3-D}$ \\
\hline 1 & $8 \mathrm{~m}$ & $8 \mathrm{~m}$ & DNA & DNA & $\sim 8 \mathrm{~m}$ & $37 \mathrm{~m}$ \\
2 & $\sim 10 \mathrm{~s}$ & $\sim 10 \mathrm{~s}$ & $3 \mathrm{~m}$ & DNA & $\sim 10 \mathrm{~s}$ & $1 \mathrm{~m}$ \\
3 & $\sim 10 \mathrm{~s}$ & $\mathrm{NU}$ & $\mathrm{NU}$ & $2 \mathrm{~m}$ & $\mathrm{NU}$ & $2 \mathrm{~m}$ \\
4 & $\sim 10 \mathrm{~s}$ & $\mathrm{NU}$ & $\mathrm{NU}$ & $3 \mathrm{~m}$ & $3 \mathrm{~m}$ & $3 \mathrm{~m}$ \\
5 & $\sim 10 \mathrm{~s}$ & $\sim 10 \mathrm{~s}$ & $50 \mathrm{~s}$ & DNA & FA & $30 \mathrm{~s}$
\end{tabular}

1. Infrared

2. Ionization

3. Rate Compensated Therma1

4. Expanding Gas

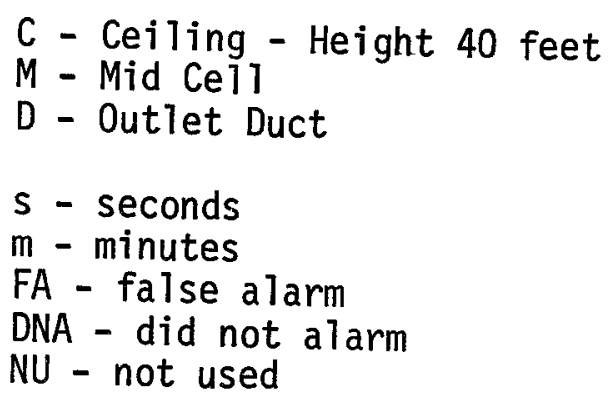


TABLE III

DETECT-A-FIRE REMOTE TEST DEVICE TESTING

\begin{tabular}{|c|c|c|c|c|c|c|c|c|}
\hline \multirow{2}{*}{$\begin{array}{l}\text { Air-Flow } \\
1300 \mathrm{fps} \\
1300 \mathrm{fps}\end{array}$} & \multicolumn{2}{|l|}{ On } & \multicolumn{2}{|l|}{$0 \mathrm{ff}$} & \multicolumn{2}{|c|}{$\begin{array}{l}\text { Approx. } \\
\text { Activation } \\
\text { Time } \\
\end{array}$} & \multicolumn{2}{|c|}{$\begin{array}{l}\text { Approx. } \\
\text { Cooling } \\
\text { Time } \\
\end{array}$} \\
\hline & $\begin{array}{l}6-1 / 2 \\
6\end{array}$ & $\begin{array}{l}\text { sec. } \\
\text { sec. }\end{array}$ & $\begin{array}{l}26 \\
24\end{array}$ & $\begin{array}{l}\text { sec. } \\
\text { sec. }\end{array}$ & 6 & sec. & 19 & sec. \\
\hline $\begin{array}{l}2700 \mathrm{fps} \\
2700 \mathrm{fps}\end{array}$ & $\begin{array}{l}8 \\
8\end{array}$ & $\begin{array}{l}\text { sec. } \\
\text { sec. }\end{array}$ & $\begin{array}{l}16 \\
15-1 / 2\end{array}$ & $\begin{array}{l}\text { sec. } \\
\text { sec. }\end{array}$ & 8 & sec. & 8 & sec. \\
\hline $\begin{array}{l}3200 \mathrm{fps} \\
3200 \mathrm{fps} \\
3200 \mathrm{fps}\end{array}$ & $\begin{array}{l}8-7 / 2 \\
7-7 / 2 \\
8-3 / 4\end{array}$ & $\begin{array}{l}\text { sec. } \\
\text { sec. } \\
\text { sec. }\end{array}$ & $\begin{array}{l}15 \\
14-3 / 4 \\
15-1 / 4\end{array}$ & $\begin{array}{l}\text { sec. } \\
\text { sec. } \\
\text { sec. }\end{array}$ & $8-1 / 2$ & sec. & 7 & sec. \\
\hline $\begin{array}{l}4100 \mathrm{fps} \\
4100 \mathrm{fps} \\
4100 \mathrm{fps}\end{array}$ & $\begin{array}{l}9-1 / 4 \\
9-1 / 2 \\
9-3 / 4\end{array}$ & $\begin{array}{l}\text { sec. } \\
\text { sec. } \\
\text { sec. }\end{array}$ & $\begin{array}{l}15 \\
14-1 / 2 \\
14-1 / 4\end{array}$ & $\begin{array}{l}\text { sec. } \\
\text { sec. } \\
\text { sec. }\end{array}$ & $9-12$ & sec. & 5 & sec. \\
\hline
\end{tabular}

Fenwal 7207 28021-0 225 $\mathrm{F}$ Detect-a-fire ARI P/N-9941 (9/73) Heater $300 \mathrm{~W}$

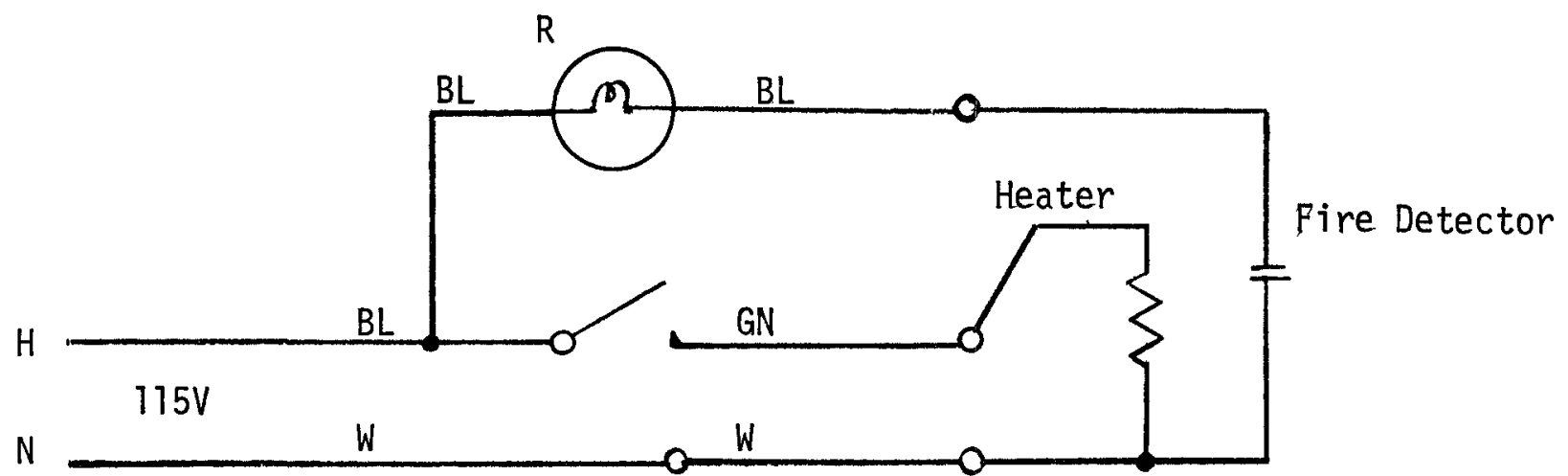

GND

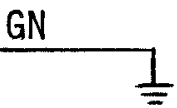

Test Assembly Wiring Diagram

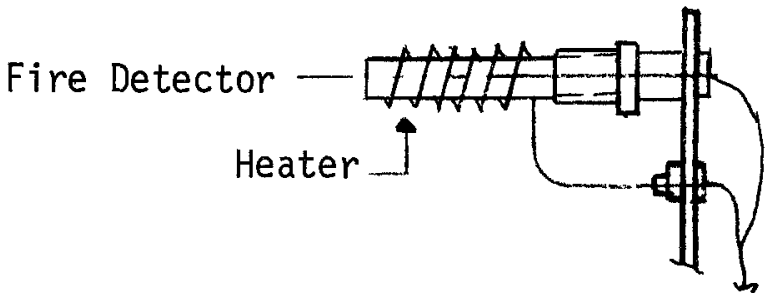

